\title{
EDUCAÇÃO MUSICAL SEGUNDO UMA PERSPECTIVA SOCIOCULTURAL: REFLEXÕES TEÓRICAS E PRÁTICAS
}

\author{
EDUCACION MUSICAL DE ACUERDO CON UNA PERSPECTIVA \\ SOCIOCULTURAL: REFLECCIONES EÓTMAS Y PRÁCTICAS
}

\author{
MUSIC EDUCATION FROM A SOCIOCULTURAL PERSPECTIVE: THEORETICAL \\ AND PRACTICAL REFLECTIONS
}

Helen Silveira Jardim de OLIVEIRA ${ }^{1}$

RESUMO: Este artigo pretende compartilhar um recorte de um dos capítulos da tese intitulada "Ensinar e aprender música: negociando distâncias entre os argumentos de alunos, professores e instituições de ensino", estudo de caso qualitativo cujo objetivo foi investigar discursos apresentados por estudantes, docentes e coordenadores de duas instituições situadas no município do Rio de Janeiro: o Colégio Pedro II e a Escola de Música de Manguinhos. As questões centrais foram: por que aprender e por que ensinar música? Essas nos remeteram à heterogeneidade dos indivíduos bem como às peculiaridades das ações didático-metodológicas dos referidos locais, fato que nos impeliu a construir um capítulo que focalizasse a perspectiva sociocultural da Educação Musical a partir dos conceitos de culturas, multiculturalismo, dos pressupostos e das diretrizes do ensino de música e da relação música e sociedade. Acredita-se que o arcabouço apresentado sirva de subsídio às discussões contemporâneas relativas ao ensino e aprendizado de música.

PALAVRAS-CHAVE: Educação musical. Perspectiva sociocultural. Ensino de música. Aprendizado de música. Reflexões teóricas.

RESUMEN: Este artículo pretende compartir un recorte de uno de los capítulos de la tesis titulado "Enseñanza y aprendizaje de la música: negociación de distancias entre los argumentos de los estudiantes, profesores e instituciones educativas", un estudio cualitativo de caso cuyo objetivo era investigar Discursos presentados por estudiantes, profesores y coordinadores de dos instituciones ubicadas en la ciudad de Río de Janeiro: el Colegio Pedro II y la Escuela de Música Manguinhos. Las preguntas centrales eran: ¿Por qué aprender y por qué enseñar música? Estos se referían a la heterogeneidad de los individuos, así como a las peculiaridades de las acciones didácticas-metodológicas de estos sitios, hecho que nos obligó a construir un capítulo que se centró en la perspectiva sociocultural de la educación musical desde el Conceptos de culturas, multiculturalismo, suposiciones y pautas de la enseñanza musical y la relación entre la música y la sociedad. Se cree que el marco presentado servirá como subvención a los debates contemporáneos sobre la enseñanza y el aprendizaje de la música.

${ }^{1}$ Universidade Federal do Rio de Janeiro (UFRJ), Rio de Janeiro - RJ - Brasil. Professora convidada do Programa de Pós-Graduação em Música da UFRJ. Líder do Laboratório de Estudo e Pesquisa em Educação Matemática nos Anos Iniciais (LEPEMAI CPII). Doutora em Educação pela UFRJ. Mestre em Música pela UFRJ. ORCID: <http://orcid.org/0000-0002-3738-9529>.E-mail: prof_helen@yahoo.com.br

RPGE- Revista on line de Política e Gestão Educacional, Araraquara, v. 23, n. 3, p. 592-622, set./dez., 2019. E-ISSN:1519-9029 
PALABRAS CLAVE: Educación musical. Perspectiva sociocultural. Enseñanza musical. Aprendizaje musical. Reflexiones teóricas.

ABSTRACT: This article aims to share a clipping of one chapter of the thesis entitled "Ensinar $e$ aprender música: negociando distâncias entre os argumentos de alunos, professores $e$ instituições de ensino", a qualitative case study whose purpose was to investigate speeches presented by students, teachers and coordinators of two institutions located in the city of Rio de Janeiro: Colégio Pedro II and the Music School of Manguinhos. The central issues were: Why learn and teach music? Those questions referred to the heterogeneity of individuals as well as to the peculiarities of the didactic and methodological actions of those sites. That fact impelled us to build a chapter focused on the sociocultural perspective of Music Education based on the concepts of cultures, multiculturalism, assumptions and guidelines of music teaching and the relations between music and society. We believe, that the framework presented can nourish contemporary discussions relating to the teaching and learning of music.

KEYWORDS: Music education. Sociocultural perspective. Music teaching. Music learning. Theoretical and practical reflections.

\section{Introdução}

O objetivo deste artigo é compartilhar um recorte de um dos capítulos da tese intitulada "Ensinar e aprender música: negociando distâncias entre os argumentos de alunos, professores e instituições de ensino", defendida no Programa de Pós-Graduação em Educação da Universidade Federal do Rio de Janeiro (UFRJ) com algumas atualizações.

A referida pesquisa consistiu em um estudo de caso de caráter qualitativo (YIN, 2010; MOREIRA; CALEFFE, 2008) e pretendeu investigar a natureza dos argumentos apresentados por estudantes, docentes e coordenadores de duas instituições: o Colégio Pedro II e a Escola de Música de Manguinhos, ambas situadas no município do Rio de Janeiro. Embora concluída no ano de 2014, acredita-se que o arcabouço aqui apresentado sirva de subsídio às discussões contemporâneas relativas ao ensino e aprendizado de música.

As questões centrais perscrutadas na pesquisa foram: por que aprender e por que ensinar música? Essas acabaram nos remetendo às diferenças socioculturais desses espaços, de seus oradores e auditórios, bem como às peculiaridades das ações didático-metodológicas desenvolvidas nesses ambientes de ensino e aprendizado de música. De modo abrangente, “oradores" são aqueles que proferem discursos com o objetivo de persuadir um auditório e "auditórios" é o conjunto das pessoas o qual o orador deseja influenciar com sua argumentação (PERELMAN; OLBRECHTS-TYTECA, 2005; LEMGRUBER; OLIVEIRA, 2011). 
Segundo Penna (2010, p. 13), a música pode ser compreendida "como uma atividade essencialmente humana, de criação de significações, e como uma linguagem culturalmente construída, de caráter dinâmico". Com base na citação, observamos que há inúmeras manifestações musicais produzidas pela imensidade de culturas existentes na sociedade que devem ser consideradas no processo do ensino e aprendizado de música.

Na medida em que alguma forma de música está presente em todos os tempos e em todos os grupos sociais, podemos dizer que é um fenômeno universal. Contudo, a música realiza-se de modos diferenciados, concretiza-se diferentemente, conforme o momento da histórica de cada povo, de cada grupo (2010, p. 22).

Se a música fosse uma linguagem universal, com certeza todo tipo de música teria significado para os indivíduos, independentemente de cultura, o que não é verossímil, por isso, concordamos que ela seja um elemento de caráter universal (PENNA, 2010; QUEIROZ, 2004, 2005), ou seja, que possui uma abrangência e é capaz de afetar e provocar algum tipo de reação em qualquer pessoa.

Além disso, Penna (2010, p. 30) afirma que: "Sendo uma linguagem artística, culturalmente construída, a música - juntamente com seus princípios de organização - é um fenômeno histórico e social". E mais:

[...] a compreensão da música, ou mesmo a sensibilidade a ela, tem por base um padrão culturalmente compartilhado para a organização dos sons numa linguagem artística, padrão este que, socialmente construído, é socialmente aprendido - pela vivência, pelo contato cotidiano, pela familiarização embora também possa ser aprendido na escola (2010, p. 31).

Se a música é um fenômeno histórico e sociocultural, podemos afirmar que, consequentemente, o seu ensino e aprendizado também o são. Sendo assim, as aulas de música podem ser compreendidas de diferentes maneiras, entre as quais um lugar dinâmico de culturas que coexistem, ora convergindo, ora divergindo, ora se mesclando. Cremos que esse processo, a nosso ver instigante e desafiador, mobiliza o docente a conhecer um pouco mais sobre a realidade do estudante e a reconhecer a importância de valorizar e incorporar elementos advindos do contexto sociocultural do discente nas aulas.

Ao optarmos por uma reflexão sobre a Educação Musical com uma ótica sociocultural, estamos reforçando uma característica fundamental de oradores e auditórios: a heterogeneidade (PERELMAN, 2004; 2005). Essa heterogeneidade se expressa de diversas maneiras, pois as diferenças são elementos intrínsecos ao ser humano.

A diversidade é uma característica da vida. Mudam as tendências de seu reconhecimento, as leis, as organizações sociais, os méritos e deméritos da Justiça, mas o ser humano não muda em sua essencial e rica perspectiva de se 
diferenciar, de não ser igual ao outro (ou de não ser o outro) (ALVARES; AMARANTE, 2016, p. 17).

$\mathrm{Na}$ primeira seção do artigo, iniciaremos abordando os conceitos de cultura e multiculturalismo. Em seguida, na segunda seção, serão focalizados pressupostos e diretrizes para o ensino de música sob uma ótica sociocultural. Prosseguiremos, na terceira seção, discorrendo sobre a relação entre música, sociedade e cultura e seus desdobramentos para a Educação Musical e aprofundaremos as reflexões articulando os conceitos de cultura e multiculturalismo à Educação Musical e a algumas categorias da teoria da argumentação. Por fim, na quarta seção, apresentaremos entendimentos e discutiremos "princípios" que envolvem concepções de Educação Musical sob uma abordagem sociocultural, trazendo olhares teóricos e práticos e resgatando conceitos e autores que foram mencionados anteriormente e outros que acrescentaram a esse debate.

\section{Pensando sobre culturas e multiculturalismo}

Santos et al. (2011) entendem que cultura envolve um universo de representações o qual a música integra. Para essas autoras da área de Educação Musical, a cultura é entendida como prática dotada de singularidade realizada no interior de grupos:

[...] a noção de cultura na contemporaneidade diz respeito a toda e qualquer produção humana, "um conjunto de representações que se manifestam em discursos, imagens, artefatos, códigos de conduta e narrativas, produzidas socialmente em relações permeadas pelo poder" (VEIGA-NETO, 2002, p. 177). Aí se encontra a música, entendida como prática social de sujeitos em um contexto em que se relacionam indivíduos, grupos e cultura. Portanto, experiência massiva e singular (2011, p. 226-227).

Já Blacking (2007), autor da área de etnomusicologia, ao tratar do conceito de cultura, apresenta as seguintes considerações:

O conceito de cultura é uma abstração esboçada para descrever todos os padrões de pensamento e interação, "um sistema organizado de símbolos significantes" (GEERTZ, 1975, 46), que persiste nas comunidades ao longo do tempo. Os instrumentos musicais e as transcrições ou partituras da música neles tocadas não são a cultura de seus criadores, mas as manifestações desta cultura, os produtos de processos sociais e culturais, o resultado material das "capacidades e hábitos adquiridos pelo homem enquanto membro da sociedade" (2007, p. 204).

Percebemos que os autores, além de evidenciarem que cultura envolve representação simbólica, destacam também suas manifestações concretas. Os autores citados consideram que 
as manifestações culturais são forjadas nas relações sociais. Com base neles entendemos que o conceito de cultura é dinâmico, pois acreditamos que a sociedade se transforma continuamente ao longo do tempo, embora persistam traços anteriores.

Outro fato a considerar é que apesar de os autores utilizarem o termo no singular (cultura), concebemos o conceito em um sentido plural (culturas), pois admitimos a presença de vários segmentos e de várias expressões culturais em uma mesma sociedade.

Santos et. al (2011) consideram que o poder permeia as relações sociais. Sendo assim, refletir sobre cultura é também refletir sobre valores e sobre as relações de poder que se estabelecem a partir desses valores. Com base nesse entendimento, podemos indagar a respeito dos valores ideais, subjacentes aos currículos, cabendo refletir acerca da pertinência de valorizar ou não as peculiaridades culturais.

Além do conceito de cultura, outros conceitos vêm sendo abordados pela literatura das áreas da Educação e Educação Musical, ampliando as possibilidades de apreender e compreender a diversidade cultural, dentre eles, o de multiculturalismo. Almejamos trazer algumas contribuições acerca do tema com o objetivo de aplicá-las às reflexões sobre as aulas de música.

Segundo Oliveira, Canen e Franco (2000, p. 115), há inúmeras possibilidades de definição do multiculturalismo.

Em um nível mais abrangente, multiculturalismo poderia ser definido como a condição das sociedades caracterizadas pela pluralidade de culturas, etnias, identidades, padrões culturais, socioeconômicos e culturais, abrangendo as formas pelas quais os diversos campos do saber incorporam a sensibilização a esta diversidade em suas formulações, representações e práticas.

Ressaltamos que, além de haver diferentes definições para o conceito de multiculturalismo, todo conceito é, inevitavelmente, polissêmico. Vale destacar que cada uma das apreensões e interpretações desse termo reflete uma visão de mundo, ou seja, um entendimento diferenciado, culturalmente condicionado.

Consideramos que uma Educação Musical com potencial multicultural deve estar aberta às tensões culturais presentes nas aulas. Por exemplo: segundo um entendimento de educação com potencial multicultural, cada aluno compreende a aula de música a partir de determinados valores e significados e com determinados objetivos em sua vida; sendo assim, consideramos que a voz dos alunos seja valorizada, ou seja, que os seus intentos em relação às aulas também sejam ouvidos. 
Vale esclarecer que a expressão potencial multicultural é apresentada por Canen, Arbache e Franco (2001) e indica uma visão de mundo que, embora não se explicite multiculturalmente, esteja atenta à diversidade, às diferenças.

Apesar de estarmos empregando o termo multiculturalismo, convém apontar que há autores que preferem adotar o termo interculturalismo. Sobre esse assunto, Canen (2007, p. 92) destaca:

[...] alguns apontam que o interculturalismo seria um termo mais apropriado, na medida em que o prefixo 'inter' daria uma visão de culturas em relação, ao passo que o termo multiculturalismo estaria significando o mero fato de uma sociedade ser composta de múltiplas culturas, sem necessariamente trazer o dinamismo dos choques, relações e conflitos advindos de suas interações.

Sobre o assunto, Penna (2010), autora da área da Educação Musical, acrescenta que:

Estudos sobre as diferentes concepções de multiculturalismo no Brasil revelam posições que se encaminham para uma perspectiva multi/intercultural, propondo uma "análise semântica" dos prefixos multi-, pluri-, inter- e trans-, tentando esclarecer o conflito conceitual dos termos. [...] A mudança de designação é justificada pela significação do prefixo inter-, que expressa o sentido de interação, troca, reciprocidade e solidariedade entre as culturas, sendo, o diálogo, imprescindível, nesta perspectiva. Nessa medida, a interculturalidade avança na direção de novas possibilidades de relação entre sujeitos e entre grupos diferentes, buscando promover o reconhecimento das diferenças culturais e, ao mesmo tempo, estabelece uma relação crítica, interativa e de dinamicidade entre elas (2010, p. 88).

Vale esclarecer que independentemente do prefixo escolhido, o que importa é a postura que se adota em relação às diferentes culturas. Sendo assim, concordamos com Penna: "a concepção é mais importante que a designação adotada. Assim, mantemos como preferencial o uso do termo multiculturalismo, até pela 'tradição' de seu uso no campo da arte" (PENNA, 2010, p. 89).

Abordando o surgimento do movimento multicultural, Gonçalves e Gonçalves e Silva (2002, p. 43) consideram que: "O multiculturalismo nasce na confluência de conflitos e de trocas entre diferentes grupos postos à margem da sociedade e aqueles que se têm por hegemônicos". Os referidos autores também exploram outros aspectos relativos aos conflitos culturais:

o multiculturalismo enquanto movimento de idéias resulta de um tipo de consciência coletiva, para a qual as orientações do agir humano se oporiam a toda forma de centrismos culturais, ou seja, de etnocentrismos. Em outros termos, seu ponto de partida é a pluralidade de experiências culturais, que moldam as interações sociais por inteiro (GONÇALVES; GONÇALVES; SILVA, 2002, p. 14) 
Em outras palavras, os referidos autores consideram que a visão multicultural se opõe às visões etnocêntricas e tem como ponto de partida a multiplicidade cultural, possibilitando assim, o engajamento em políticas multiculturais.

Eles ainda acrescentam que o fenômeno multiculturalista teve início em países em que a heterogeneidade é considerada um "problema" para a construção da identidade (no sentido de unidade) nacional. O multiculturalismo aparece como princípio orientador das ações de minorias culturalmente dominadas às quais foi negado o direito de conservarem suas características culturais.

Com base em Canen (2002; 2007), é possível conceber o multiculturalismo sob três pontos de vista: liberal ou folclórico, crítico ou intercultural crítico, pós-moderno ou póscolonial. Esclareceremos cada um deles a seguir.

O multiculturalismo liberal ou folclórico envolve a concepção de uma sociedade harmoniosa, sendo a diversidade cultural visualizada em termos exóticos. Ele também possui uma visão essencialista, ou seja, reconhece-se a diversidade cultural, mas não se realiza nenhuma reflexão crítica sobre como ela ocorre no âmbito das relações sociais. "Nessa perspectiva, o multiculturalismo é reduzido a um adendo ao currículo regular, definido como a comemoração de datas especiais [...] e assim por diante.” (CANEN, 2002, p. 63).

No multiculturalismo crítico ou perspectiva intercultural crítica, o foco da discussão reside no questionamento da construção das identidades e diferenças. Há uma percepção de que essa construção não é neutra ou inocente, ou seja, não sendo afastada das relações de poder (CANEN, 2007).

Já o multiculturalismo pós-moderno ou pós-colonial tem como conceito central o hibridismo ou hibridização. Segundo essa perspectiva, há múltiplas marcas que formam um indivíduo híbrido e cada um não abriga uma essência única e fixa e sim uma identidade dinâmica que se constrói e reconstrói permanentemente. Sobre esse assunto, Canen (2007, p. 95) acrescenta:

Souza Santos (2001) alerta que o multiculturalismo crítico pós-colonial discute as "diferenças dentro das diferenças", recusando a ideia de que as identidades plurais que constituem a sociedade sejam estáticas, unas, indivisíveis. De fato, nesta visão, não haveria tipos identitários 'puros': as sínteses culturais fazem com que todos sejamos constituídos no hibridismo.

Valorizar os saberes dos alunos e considerá-los em termos curriculares é compreender que a sala de aula é um ambiente multicultural. Sendo assim, identificamo-nos com a perspectiva multiculturalista pós-colonial, pois acreditamos que sínteses culturais ocorrem a 
todo tempo no processo das aulas de música: sínteses entre oradores e auditórios e também entre auditórios.

Cremos que a visão multiculturalista em aulas de música deve superar a simples constatação das diferenças culturais. Também entendemos que não devemos permanecer somente no questionamento de como tais diferenças são construídas e sim perceber e aprender a lidar com indivíduos que influenciam e são influenciados culturalmente, formando híbridos culturais. Com base em Souza Santos (2001), consideramos que, se somos constituídos no hibridismo, seria incoerente afirmar que há pureza cultural em se tratando do trabalho pedagógico.

\section{Pressupostos e diretrizes para o ensino de música sob uma ótica sociocultural}

Freire (2011) é umas das autoras da Educação Musical que, inicialmente, procurou entender a música em sua inserção na sociedade. Ao longo do tempo seu pensamento transitou para a concepção pós-moderna devido à maior flexibilidade teórico-metodológica, à possibilidade de relativizar conceitos e à valorização e confrontação de diferentes opiniões.

Sobre diferenças culturais, Freire aborda alguns aspectos do paradigma científico pósmoderno de pensamento valorizados por pesquisas recentes na área de Educação Musical que são convergentes e se coadunam com o olhar multicultural. Sendo assim, podemos relacionar algumas características da pedagogia pós-moderna, aplicadas à Educação Musical, descritas pela autora:

[...] a legitimação das diferenças, focalizando diferentes técnicas de criação, diferentes sonoridades e sistemas musicais, com uso frequente de abordagens etnográficas [...] a valorização e a ampliação do conceito de cultura, segundo um enfoque pluralista, concedendo maior espaço às trocas e reelaborações de características musicais e às experiências do cotidiano dos alunos, relativizando os pontos de vista e de escuta. [...] ênfase em metodologias de ensino que dão destaque às experiências musicais do aluno e às trocas entre processos informais, não-formais e formais de ensino de música [...] a valorização das percepções e depoimentos de todos os atores envolvidos em um processo educacional, inclusive dos alunos ou de pessoas não-letradas, considerados como relatos válidos [...] (FREIRE, 2011, p. 13).

Em relação à música, a autora assume alguns pressupostos. O primeiro deles fundamenta-se em Read (1982): “[...] arte e sociedade são conceitos inseparáveis, o que leva à afirmação de que música e sociedade também o são" (2011, p. 21). A autora acrescenta que 
além de arte e sociedade serem inseparáveis, seria impossível admitir a existência de uma sociedade sem arte, ou uma arte sem significado.

Sendo assim, com base em Freire e em Read, acreditamos que se a música é uma das instâncias da sociedade, portadora de características históricas, políticas e culturais, também não podemos vislumbrar a Educação Musical distanciada dessas características.

O segundo pressuposto apontado pela autora, fundamentado em Cassirer (1977) e Read (1981; 1982), é o de que a arte também é uma forma de conhecimento e permite uma interpretação de mundo de modo peculiar, diferindo, assim, do pensamento científico. Realizando uma apropriação desse pressuposto à música, podemos compreender que a mesma também propicia geração de conhecimentos específicos e uma visão de mundo diferenciada.

O terceiro pressuposto assumido por Freire (2011, p. 22), baseado em Fischer [s.d.] e Read (1982), revela-nos que: “a missão da arte é ajudar a compreender e a transformar o homem e o mundo, o que a torna inseparável de uma concepção política, aqui entendida como ação transformadora". Ou seja, a autora trata a música como um artefato político dotado de potencial para transformar o homem e a sociedade. Segundo Freire, a música contribui para a conscientização e para a construção de um saber crítico, propiciando ao indivíduo um aprimoramento ético.

Sekeff (2007, p. 169) também possui um entendimento sobre educação que coincide com a perspectiva de Freire (2011) quando afirma que "é nas artes que germinam articulações de práticas libertadoras e consciência de cidadania". Vale ressaltar que, a nosso ver, não somente as artes podem possibilitar esse processo, mas também outras áreas de conhecimento. Segundo a autora, a música sustenta a criação de uma consciência individual, mas também coletiva, promovendo, dentre outros elementos, a consciência de cidadania do educando.

Não há, pois, que subestimar sua capacidade como matriz de conhecimento nem seu poder de expressão e mobilização, uma vez que, como produto e reflexo da sociedade e de um momento histórico, música é função atuante no devir da humanidade (SEKEFF, 2007, p. 171)

De acordo com Freire, os mesmos pressupostos que podem ser utilizados quando refletimos sobre a educação também podem ser direcionados à Educação Musical. A educação, assim como a arte, num primeiro momento influencia e é influenciada pela sociedade, isto é, há uma relação dialética entre ambas. A educação também é um instrumento essencial e catalisador da mudança tanto do indivíduo quanto da sociedade.

No que concerne à educação, também os pressupostos assumidos transparecem numa abordagem dialética, na medida em que consideram a 
educação articulada com o ambiente histórico-concreto, ou seja, como elemento (determinado e determinante) de um processo de relações sociais múltiplas, potencialmente importantes no processo de transformação do homem e da sociedade (FREIRE, 2011, p. 186).

A referida autora propõe sete princípios ou diretrizes para o ensino de música, que foram inspirados na concepção dialética da educação. A autora destaca que os mesmos não seguem uma sequência ou hierarquia: "1) historicidade; 2) criação de conhecimento; 3) preservação de conhecimento; 4) reflexão crítica e elaboração teórica; 5) prática atual; 6) implicação política; 7) expressão estética.” (2011, p. 187). Abordaremos, a seguir, sucintamente, cada princípio (ou diretriz) segundo a referida autora.

A historicidade engloba as relações sociais passadas, presentes e também futuras, que já se manifestam na música no presente. Essas relações encontram-se em constante dinamismo. O compromisso com este princípio implica num entendimento de que a arte não é alienada e que o seu conteúdo não se estabiliza sem relação ao tempo e espaço. O princípio de historicidade faz-nos pensar que não há uma música universal, uma espécie de modelo a ser seguido, e sim, músicas de diversos períodos históricos que circulam entre sociedades e que estão num processo de transformação contínua.

Fazer e pensar música, a partir do princípio de historicidade é, sobretudo, dar conta da música hoje, mas não da música "séria", derivada da tradição europeia, pois a história contemporânea abriga múltiplas concepções de música [...], concepções essas contraditórias e coexistentes, que não podem, a partir de tal princípio, ser excluídas. Mas é também dar conta da música do passado, não como parâmetro ideal para o pensar e o fazer música, mas como elemento significativo de uma história que não se quer apagar, mas compreender e apreender (FREIRE, 2011, p. 188).

O segundo princípio, o de criação de conhecimento, assim como o de historicidade, considera que toda manifestação musical se dá em movimento contínuo, permanente, sofrendo modificações ao longo da história. A criação constante de conhecimento faz com que não haja uma imobilização de conteúdo, incentivando também uma reflexão constante a respeito do que é produzido ou reelaborado. "Criar conhecimento permanentemente não significa excluir ou desprezar os conhecimentos e conteúdos do passado, mas significa não parar neles" (FREIRE, 2011, p. 189).

O terceiro princípio, a preservação de conhecimento, que também está relacionado aos anteriores, aponta para a consciência de que há um acervo cultural produzido pela humanidade que sempre será renovado a partir das reflexões críticas e recriação permanente promovidas pela sociedade. Ou seja, preservar, nesse caso, não está associado às ideias de imobilização ou 
cristalização. Preservar conhecimento não significa, por exemplo, reproduzir acriticamente repertórios musicais, mas sim, revitalizados com novos olhares. Freire acrescenta que

Preservar conhecimento não significa, também, preservar um tipo privilegiado de conhecimento, mas garantir espaços para todos os tipos de conhecimento do popular ao erudito, do folclórico à cultura de massa [...] é debruçar-se sobre os conteúdos e repertórios do passado e do presente, preservando a historicidade e a dinâmica que eles carregam, reconhecendo seus referenciais espaciais, temporais, culturais de modo a poder analisá-los criticamente e gerar novos conteúdos e repertórios enriquecidos (FREIRE, 2011, p. 190).

O quarto princípio, que se refere à reflexão crítica, procura abrir espaço para questionar os limites, verdades, valores e visões de mundo a fim de que haja possibilidade permanente na educação para reelaboração, revalorização e reinterpretação de fatos e fenômenos. Esse questionamento crítico pode gerar transformação e conscientização social sobre teorias e práticas, entendidas pela autora como inseparáveis. Segundo Freire (FREIRE, 2011, p. 191): "Reflexão crítica e elaboração teórica permanentes, como princípio, implicam em conceber o conhecimento, prático ou teórico, como transitório, como permanentemente inacabado, passível de recriação permanente".

O quinto princípio, o da prática atual, está comprometido com as modalidades musicais que estão presentes e se hibridizam no mundo contemporâneo. Esse processo de mescla, em muitas situações, provoca conflitos e contradições, gerando novos conhecimentos.

Nesse sentido, a música "séria" dos séculos anteriores tem seu espaço garantido, desde que a consciência histórica do homem voltou seus olhos para a música do passado e buscou reaprendê-la. Não cabe, sobretudo, torná-la o centro do processo de ensino, em detrimento das outras concepções de música, principalmente as que são produzidas no contexto de nossa época. Conteúdos, repertórios, técnicas, treinamentos, todos estariam comprometidos com a prática atual e teriam que abrigar a multiplicidade de manifestações musicais e refletir sobre elas (FREIRE, 2011, p. 193).

A autora acrescenta que a prática atual se expressa através de ações que podem ser individuais ou coletivas. Por exemplo, a prática de um músico não se esgota na reprodução de uma obra musical, pois ele pode chegar a um ápice artístico criando/recriando tal obra, empregando sentimentos, significados e sentidos de modo peculiar. Desta forma, esse princípio, além de abranger a totalidade das práticas musicais (de diversas épocas, culturas e sistemas musicais), abarca a totalidade do ato artístico como inacabado.

O princípio da implicação política (sexto princípio) envolve uma perspectiva de transformação do homem e da sociedade em que o mesmo está inserido. De acordo com esse princípio, o indivíduo é capaz de construir a sua própria história. 
Neste sentido, educação e política seriam inseparáveis, logo, o ensino oferecido pela escola tem um papel político a ser desempenhado. Freire aborda a politização dos conteúdos, ou seja, durante o trabalho pedagógico os conteúdos deveriam ser criticados e contextualizados socialmente, conferindo aos mesmos significados renovados. A compreensão global de um fenômeno, fato, ou sistema musical não se dá pelo isolamento, e, sim, pela inserção na totalidade das relações que permeiam ou permearam os mesmos.

E por fim, temos o sétimo princípio que se refere à expressão estética, ou seja, à experiência sensível que a arte propicia ao homem, assegurando que o mesmo tenha um desenvolvimento pleno. Arte, segundo a mesma autora, é conhecimento (READ, 1981; FISCHER, s.d.) gerado pela experiência estética que não exclui a dimensão social implícita:

[...] é preciso considerar que estética pressupõe escolha, e escolha pressupõe valores; e valores só existem em interação com a cultura, ou seja, com a sociedade. Dar conta da dimensão estética é dar conta das relações sociais em que as concepções estéticas se inserem, é dar conta do dinamismo dessas concepções, na totalidade de que fazem parte. [...] Compromisso com a estética é compromisso com as relações sociais em sua totalidade, com o movimento dessas relações e com o movimento e com a transformação das próprias concepções estéticas, decorrentes das contradições inerentes aos contextos em que se inserem (FREIRE, 2011, p. 196).

Consideramos que estes princípios são atuais e permitem uma flexibilização do ensino da música independentemente de tempo e espaço. Eles apontam para uma maior relação da Educação Musical com a sociedade e para a valorização das culturas presentes, não de maneira passiva, mas ativa, crítica, conscientizadora. Reforçamos que compreender a música como uma das instâncias da sociedade é conceber a Educação Musical também como um dos elos constituintes dessa sociedade.

\section{Relacionando música, sociedade e culturas}

Ao refletir mais sobre as características da sociedade, sociedade essa que se relaciona dialeticamente com a música, reforçamos que, se temos a compreensão de que as sociedades são plurais, é incoerente conceber uma Educação Musical que não esteja sensível para tal fato porque a pluralidade também se revela em termos culturais. Cada sociedade possui um arcabouço musical que exerce impactos diferenciados em cada contexto de acordo com os aspectos estéticos, artísticos e culturais presentes na mesma.

Levando em conta essa pluralidade, Queiroz considera que existe relação entre música, sociedade e cultura, compreendendo a música como fenômeno sociocultural. 
A música transcende os aspectos estruturais e estéticos se configurando como um sistema estabelecido a partir do que a própria sociedade que a realiza elege como essencial e significativo para o seu uso e a sua função no contexto que ocupa. Essa perspectiva tem conduzido importantes reflexões no campo da educação musical, levando-nos a compreender que um ensino significativo de música deve entender esse fenômeno não só como expressão artística, mas, principalmente, como manifestação representativa de sistemas culturais determinantes do que o homem percebe, pensa, gosta, ouve, sente e faz (2005, p. 50).

O entendimento de música como manifestação cultural, adotado por Queiroz, tem inspiração nos estudos oriundos da etnomusicologia. Fundamentado nos estudos dessa área, o autor concebe que a Educação Musical deve se constituir num espaço de formação de valores e a mesma não deve apenas "se relacionar com a cultura, mas, sobretudo, compor a sua caracterização, ou seja, desenvolver um ensino da música como cultura" (2004, p. 100, grifo do autor).

Reconhecemos que a Educação Musical muito tem a ganhar dialogando com a área de etnomusicologia, devido à relação que a música possui com a cultura e com os valores produzidos por ela.

[...] a educação musical contemporânea tem se preocupado em valorizar, entender, compartilhar e dialogar com músicas de diferentes contextos, proporcionando uma interação entre os processos de ensino-aprendizagem da música dentro da escola com os demais processos vivenciados no mundo cotidiano do indivíduo. Nesse sentido a educação musical tem se aproximado e se apropriado do campo de estudo da etnomusicologia com o intuito de tornar a sua práxis mais significativa e contextualizada com os distintos mundos musicais que se confrontam e interagem dentro das escolas, específicas ou não, que se dedicam ao ensino da música (QUEIROZ, 2004, p. 102).

Queiroz reitera, através de outras palavras, a interação dialética entre música e cultura, bem como a importância de que se leve esse entendimento à Educação Musical, aproximandose, dessa forma, da concepção de Freire (2011):

Pensar a música como expressão humana contextualizada social e culturalmente é fator fundamental para estabelecermos ações educativas que possam ter consequências relevantes na sociedade e na vida das pessoas que constituem o universo educacional, tendo em vista que cada meio determina aquilo que é ou não importante e o que pode ou não ser entendido como música. [...] Dessa forma, fica evidente que a música como cultura é definida a partir de suas inter-relações sociais, sendo também definidora de aspectos importantes para a caracterização identitária de uma determinada sociedade (2005, p. 54-55). 
A partir das contribuições de Freire e Queiroz a respeito da música e de como essa se relaciona com a sociedade e a cultura, percebemos que, enquanto Freire concebe a música como um dos elos, ou seja, uma das instâncias da sociedade, sociedade essa que tem elementos culturais que a caracterizam, Queiroz enfatiza o entendimento de que a música pode ser considerada como cultura, definida por intermédio da relação do indivíduo com a sociedade.

Apesar de a visão de Freire apontar para a inseparabilidade de música e sociedade e a de Queiroz e Sekeff sugerirem que sociedade e música são, até certo ponto, instâncias independentes (a sociedade - o meio - determinaria o que é ou não música), percebemos que os autores possuem algumas convergências e apontam caminhos interessantes e possíveis e que também podem integrar as discussões promovidas pela Educação Musical.

Trilhando pela mesma ótica sociocultural apontada por Freire (2011) e Queiroz (2004, 2005), Santos et al. (2011) afirmam que as escolhas, práticas musicais e formas distintas de se utilizar a música caracterizam os grupos sociais. Isso significa que podemos ter auditórios que são caracterizados pelo tipo de música que apreciam, que executam, ou seja, ao qual aderem. É válido destacar que o tipo de música que pode unir certos auditórios também pode afastar outros.

\begin{abstract}
A música é um dos caminhos de produção de identidades culturais. As pessoas se agrupam socialmente através das práticas musicais. Estudos musicológicos já nos ajudaram a entender que a música é um "fato social total" (MOLINO s/d, p. 114), e que é muito próprio falar em músicas, cada qual definida culturalmente (HERNDON; MCLEOD, 1980). Os usos que os grupos sociais fazem da música são os mais variados e sempre há um valor a ela atribuído pelos sujeitos que vivem daquela prática e nela se reconhecem (SANTOS et. al., 2011, p. 224, grifo das autoras).
\end{abstract}

Acrescentamos que cada manifestação musical é a expressão de uma ou mais identidades, identidades essas que se relacionam a um mundo de significados. Nesse sentido, entendemos que a Educação Musical pode exercer um papel de mediação e de conscientização entre a identidade do indivíduo e a música praticada por ele. Sobre o assunto, Queiroz (2004, p. 105-106) afirma que

a música na e como cultura representa uma forte e complexa fonte de significados, sendo parte intrínseca da experiência de cada sujeito, atuando como um dos fatores essenciais para a expressão do homem em suas interações sociais. Cabe à educação musical o papel de possibilitar caminhos para que a relação entre o homem e a música se efetive de forma significativa, contextualizada com os objetivos de cada indivíduo e com a sua realidade sociocultural. 
Partindo da concepção de que há múltiplas manifestações musicais geradas por grupos distintos, Queiroz considera que não seria coerente dizermos que a música é uma linguagem universal e sim, que a mesma se constitui num veículo universal, um instrumento de proporção universal. Ou seja, mesmo utilizando a palavra música no singular, sua apreensão, em termos culturais, é plural (músicas).

\begin{abstract}
A música, pensada em relação à cultura, poderia ser considerada como um veículo "universal" de comunicação, no sentido que não se tem notícia de nenhum grupo cultural que não utilize a música como meio de expressão e comunicação (NETTL, 1983). É importante notar que com essa afirmação não estamos concebendo a música como uma "linguagem universal", pois tal concepção seria errônea, tendo em vista que cada cultura tem formas particulares de elaborar, transmitir e compreender a sua própria música, (des) organizando os códigos que a constituem (QUEIROZ, 2005, p. 101).
\end{abstract}

Admitimos, assim, que é impossível compreender, de forma unívoca e em sua totalidade, as linguagens musicais de cada cultura, pois cada uma delas é dotada de especificidades. Todavia, mesmo com essa limitação, cabe à Educação Musical propiciar a interação com músicas vindas de diferentes contextos, tanto para ampliar o universo musical dos alunos quanto de nós mesmos como docentes.

O pensamento de Penna é também compatível com o de Queiroz sobre o fato de a música ser um fenômeno universal, já que a mesma é construída culturalmente. Ela observa que

Exatamente porque a música é uma linguagem cultural, consideramos familiar aquele tipo de música que faz parte de nossa vivência; justamente porque o fazer parte de nossa vivência permite que nós nos familiarizemos com os seus princípios de organização sonora, o que a torna uma música significativa para nós. Em contrapartida, costumamos "estranhar" a música que não faz parte de nossa experiência (PENNA, 2010, p. 23).

Sendo assim, podemos refletir que, se a música não está sendo entendida como uma linguagem universal, consequentemente, os processos de ensino e aprendizagem e as metodologias de ensino utilizadas não são universais. Consideramos que as mesmas devem ser coerentes com cada situação cultural e com os "múltiplos contextos em que se ensina, aprende e vive música" (QUEIROZ, 2004, p. 104).

Consideramos que antes de a Educação Musical contemplar diferentes abordagens educacionais, ela deve se preocupar com a abordagem de diferentes conteúdos, a fim de que haja uma construção de conhecimento musical mais rica, ampla e consistente. Em suma, defendemos que os docentes considerem as inúmeras possibilidades didático-metodológicas sem descartar a variedade de conteúdos musicais. 


\section{Concepções socioculturais da Educação Musical: olhares para a teoria e prática}

Após refletirmos sobre as categorias das seções anteriores, prosseguimos nossas reflexões discutindo de forma mais detalhada alguns aspectos relativos à concepção de Educação Musical sob uma ótica sociocultural nos parágrafos seguintes.

Queiroz (2003, p. 3) apresenta-nos um papel fundamental da educação na citação a seguir: “[...] a educação poderia e deveria ser o principal e mais importante caminho para estimular a consciência cultural do indivíduo, começando pelo reconhecimento e a apreciação da 'cultura local', pois reconhecer sua própria cultura é conhecer a si próprio”. Consideramos, com base no autor, que essa consciência cultural sempre será dinâmica, em permanente transformação, e que é essencial que a Educação Musical contribua no despertar dessa consciência.

Há muito tempo a música de matriz eurocêntrica tem sido considerada de valor universal ideal, enquanto outras músicas nem sempre têm sido valorizadas. Esta valorização vem sendo revista por muitos educadores musicais, face às tendências teóricas recentes que enfatizam a pluralidade cultural, mas ainda existe um caminho a percorrer. Sobre o assunto, Queiroz afirma que

A música como fenômeno cultural constitui uma das mais ricas e
significativas expressões do homem, sendo produto das vivências, das
crenças, dos valores e dos significados que permeiam sua vida. [...] a música
como cultura cria mundos diversificados, mundos musicais que se
estabelecem não como universos e territórios diferenciados pelas linhas
geográficas, mas como mundos distintos dentro de um mesmo território, de
uma mesma sociedade e/ou até dentro de um mesmo grupo (2005, p. 52 e 53).

Percebemos, na citação de Queiroz, que as diferentes e significativas expressões musicais dos indivíduos criam diferentes mundos musicais: mundos que se opõem, dialogam e que muitas vezes se hibridizam. Quando refletimos sobre esses mundos, temos uma visão macro, acentuando, por exemplo, diferenças entre alunos brasileiros e de outros países. Todavia, esses mundos musicais distinguem-se numa mesma sociedade, num mesmo grupo, isto é, num mesmo auditório. Assim sendo, nós como educadores, devemos estar sensíveis para tal fato.

Integrada à prática escolar, a diversidade cultural, que também se traduz numa diversidade musical, pode e deve ser um instrumento para melhor dialogar e conviver com as semelhanças e diferenças culturais existentes no ambiente educacional. Sendo assim, entendemos que a Educação Musical deva considerar as diferenças entre oradores e auditórios 
e a existência de diversos sotaques, discursos e universos musicais, aceitando-os não de uma forma ingênua, mas empreendendo um olhar crítico sobre as mesmas.

Compreendendo a necessidade de uma educação que abranja os diferentes "universos" de uma cultura e os distintos discursos e "sotaques musicais" presentes em cada realidade, a educação musical brasileira tem focado sua atenção sobre os diferentes universos musicais do nosso país, buscando interrelacionar aspectos mais abrangentes, "plurais", do ensino da música com particularidades que configuram a nossa identidade musical. Identidade que nos singulariza pela sua dimensão plural, de universos distintos, que caracterizam os diferentes mundos musicais do Brasil, tornando este país um contexto cultural/musical que possui músicas de diferentes significados, usos e funções, simbolizando a diversidade identitária de uma cultura, a cultura brasileira (QUEIROZ, 2004, p. 99).

É importante que as aulas de música incorporem aspectos oriundos das culturas dos alunos (dos mundos culturais) de forma significativa e relevante para os mesmos, a fim de conquistar sua adesão para as aulas. Consideramos adesão, nesse caso, uma participação ativa, uma recepção às propostas que possa contribuir para a construção de conhecimento musical dos estudantes.

Sobre esse assunto, Queiroz afirma, com base em Blacking (1995), que

[...] o contexto social é gerador de aspectos motivadores para a experiência musical, sendo uma característica intrínseca à música dentro do seu sistema cultural [...] Assim, estaremos fugindo da cultura musical frágil e superficial consolidada, muitas vezes, dentro das aulas de música em instituições formalizadas. Cultura que cria "musiquinhas" e "brincadeirinhas musicais" sem qualquer significado real para os seus praticantes, gerando consequentemente, desinteresse e descaso dessas pessoas para com as aulas de música (2005, p. 54).

Considerar a diversidade cultural é trabalhar com situações que se aproximem o máximo possível da realidade dos alunos. Para que isso ocorra, entendemos que o conhecimento do auditório é fundamental no processo educativo, pois o mesmo trará elementos para que o processo argumentativo aconteça de maneira satisfatória. Conhecendo o auditório, será possível promover a negociação de distâncias defendida por Meyer (2002) de uma melhor forma. Meyer defende que há uma distância entre orador e auditório que pode ser expandida ou minorada. Segundo o próprio, a "retórica é a negociação da distância entre os indivíduos a propósito de uma questão" (2002, p. 268, grifo do autor), isto é, algo está em questionamento porque é passível de indagação.

Meyer reconhece a multiplicidade de aspectos que permeia as diferenças existentes entre orador e auditório. Logo, podemos depreender que a negociação de distâncias pode ser considerada um processo que é 
simultaneamente heterogêneo, singular e árduo. Heterogêneo pelo fato de orador e auditório serem pessoas com características distintas. Singular porque não ocorre da mesma maneira entre indivíduos, sendo um momento ímpar. E árduo, pelo fato de haver, muitas vezes, desgaste pessoal nos momentos de debate e discussão (OLIVEIRA; OLIVEIRA, 2018, p. 209).

Articulando, neste momento, Educação Musical e multiculturalismo, apresentamos as contribuições de Penna (2010), que defende uma ótica multicultural em relação ao ensino de música. A autora entende a arte através de um conceito amplo e propõe que sejam abarcadas as diversas manifestações artísticas presentes nas aulas de música.

O multiculturalismo no ensino de arte implica uma concepção ampla de arte, capaz de abarcar a múltiplas e diferenciadas manifestações artísticas, e o mesmo se coloca no campo específico da educação musical. Uma concepção ampla de música é, por um lado, uma condição necessária para que a educação musical possa atender à perspectiva multicultural. Por outro lado, a concepção da multiculturalidade contribui para a ampliação da concepção de música que norteia nossa postura educacional (PENNA, 2010, p. 90).

Percebemos em muitas situações que a música que não integra nosso ambiente sociocultural é vista com estranhamento. Não queremos aqui abrir uma discussão sobre as produções vindas da indústria musical e sua influência nas massas e sim observar que, por motivos variados, realizamos escolhas musicais e que as mesmas não são neutras.

O professor também não é neutro em suas escolhas! O que propomos é que haja uma abertura para que elas possam ser compartilhadas, discutidas e ressignificadas. Valendo-nos da terminologia da teoria da argumentação, o que estamos defendendo é que esteja presente nas aulas de música não apenas a escolha do orador (nesse caso, o professor), mas também a do seu auditório (grupo de alunos). Enfim, defendemos que a pluralidade cultural existente faça parte de uma relação dialógica.

Se, como professores, nos mantivermos presos a nossos padrões pessoais, presos a nosso próprio gosto, ou simplesmente às indicações de algum livro didático, pois nossa tendência será desconsiderar, desqualificar e desvalorizar a vivência do aluno - a sua música, a sua dança, a sua prática artística, enfim. Pelo contrário, a possibilidade de buscar e construir os caminhos necessários para o diálogo intercultural inicia-se com a disposição em olhar para o aluno e acolher as suas práticas culturais. E essas práticas podem significar bem mais do que mera questão de gosto pessoal, dizendo respeito às histórias de diferentes grupos, nas suas lutas pelo direito a sua especificidade e a seus valores próprios (PENNA, 2010, p. 100).

Percebemos também uma aproximação do multiculturalismo com a teoria da argumentação e com as questões da Educação Musical, segundo um entendimento sociocultural, quando nos propomos a persuadir os sujeitos a se afastarem da intolerância, a 
modificarem as suas atitudes, a iniciarem uma reflexão sobre as diferenças culturais presentes no espaço escolar.

Além dos aspectos anteriormente apontados, Freire, tendo como base Giroux e Simon (1995) levanta algumas questões a serem refletidas pelos docentes, sendo convergentes com as considerações de Penna (2010) e também com a concepção multicultural.

1) Que relação meus alunos veem entre o trabalho que fazemos em classe e as vidas que eles levam fora da sala de aula?

2) Seria possível incorporar aspectos da cultura vivida dos alunos ao trabalho de escolarização, sem simplesmente confirmar aquilo que já sabem?

3) Seria possível fazê-lo sem banalizar os objetos e relações que são importantes para os alunos?

4) E seria possível fazê-lo sem discriminar determinados grupos de alunos como marginais, exóticos e "outros" dentro de uma cultura hegemônica? (2001, p. 72).

A autora ainda defende que devemos fazer a inclusão das culturas dos alunos nas aulas de música, respeitando cada uma delas, pois refletem manifestações musicais do seu dia-a-dia, de sua vivência.

Com certeza as questões levantadas pela autora não possuem respostas simples e fechadas, mas tocam em pontos nodais das discussões empreendidas pelos estudos da área de Educação Musical atualmente.

Queiroz (2004; 2005) nos traz algumas perspectivas para uma concepção de Educação musical abrangente, que, a nosso ver, estão intimamente relacionadas com a heterogeneidade dos auditórios (PERELMAN; OLBRECHTS-TYTECA, 2005; LEMGRUBER; OLIVEIRA, 2011) e também com as considerações de Freire (2011). Ousamos afirmar que as contribuições do referido autor poderiam ser encaradas como possíveis respostas para as questões que Freire nos apresentou anteriormente.

Ele considera que reconhecer a vivência dos alunos é fundamental, mas não podemos nos esquecer de que o nosso compromisso como educadores é de ampliar os conhecimentos musicais dos alunos. Ou seja, ele propõe que haja um diálogo permanente entre a cultura do professor e dos alunos, porém destaca que tomar como ponto de partida para o trabalho pedagógico elementos que os alunos trazem da sua realidade não significa permanecer nela.

Queiroz também nos alerta que o contex to sociocultural não pode ser considerado como inicial, apenas para incentivar os alunos, por não trazer subsídios para oferecer aos próprios uma formação musical "adequada". Os conhecimentos trazidos pelos alunos devem e podem contribuir para uma Educação musical ampla. Caberá ao professor, promover as adaptações e inserções necessárias, pois 
[...] espera-se da educação musical não somente uma conformidade com o sistema cultural de uma sociedade, mas sim uma interferência neste, possibilitando a autonomia dos seus sujeitos para configurar novas concepções de música e suas relações. Partir da realidade cultural dos alunos não significa ficar nela. É importante que sejam oferecidas novas opções e descobertas para que a música seja experimentada, (re)criada e (re)vivida de forma musical, significativa para a própria experiência de vida de cada ator envolvido no processo de educação musical (QUEIROZ, 2004, p. 105).

Ainda segundo o autor, "deselitizar" os repertórios a serem trabalhados é um desafio constante, isto é, não há melhor e pior música ou canção a ser utilizada: devemos perceber que tipo de conteúdo (contribuição) cada uma delas pode proporcionar para promover a aprendizagem musical. "Deselitizando" os repertórios, temos assim, uma abertura para músicas de variados tipos e sistemas musicais sem restringir o conhecimento e o aprimoramento musical/estético dos alunos.

Considerar a música como fenômeno sociocultural significa entendê-la como
algo que insere a prática artístico-musical numa rede de sistemas mais
complexa, onde é preciso muito mais que música, enquanto fenômeno sonoro,
para caracterizar uma expressão representativa e presente no universo cultural
dos seus praticantes. Essa perspectiva nos conduz a novos direcionamentos
para a educação musical. Direcionamentos que nos levam a caminhos mais
abrangentes, que reconhecem a inexistência de uma única música e valorizam
as distintas e variadas manifestações musicais (QUEIROZ, 2005, p. 62).

Percebemos que através do diálogo, da valorização das culturas musicais presentes com o objetivo de construir e ampliar o conhecimento musical - e da deselitização dos repertórios é possível incorporar aspectos da cultura dos alunos sem banalizar os que os mesmos consideram importante, afastando a discriminação em relação a certos grupos de alunos, pois todos terão voz, inserindo-os, portanto, no processo educacional como auditórios e como oradores.

Desta maneira, podemos assegurar aos alunos uma experiência satisfatória e consistente no processo de Educação musical oferecendo espaço para a música do seu cotidiano nas aulas. Neste sentido, cremos que os elementos trazidos por Queiroz $(2004$; 2005) tenham respondido a algumas questões levantadas anteriormente por Freire (2001).

Observamos que, muitas vezes, devido à falta de tempo, à pressões vindas do cumprimento de um plano curricular mais rígido e, até mesmo, à dificuldades metodológicas, ou seja, ao despreparo dos educadores para lidar com as diferenças socioculturais em sala de aula, desconsideramos as questões levantadas por Freire. Realizar uma aula de música a partir de uma perspectiva mais homogênea seria um caminho mais "fácil" a trilhar; no entanto, 
realizar aulas homogêneas com auditórios heterogêneos gera dificuldades diversas que devem ser consideradas, pois

[...] os alunos constituem, como foi dito, auditórios heterogêneos, seja porque são oriundos de meios sociais diversos daquele no qual se insere o professor, seja por razões de natureza religiosa, étnico-racial ou outras quaisquer. Assim sendo, suas histórias de vida não são apagadas quando entram nas salas de aula, levando-os a "medir" os docentes em termos de conhecimentos, crenças, valores, hábitos e atitudes muito diferentes. $\mathrm{O}$ confronto entre aquilo que os estudantes pensam e são e o que lhes é indicado pelos professores como modo correto de ser e de agir torna-se, assim, inevitável (OLIVEIRA, 2011, p. 93).

Outra ponderação que podemos apresentar é que se admitimos a existência de uma diversidade cultural que também se revela em termos musicais, devemos dispor de diversas estratégias de ensino. Por conseguinte, é fundamental estabelecer um diálogo entre as diferentes instâncias de ensino (formais e informais) que trabalham com Educação Musical.

Da mesma forma que entendemos a diversidade musical, necessitamos entender que é necessária uma diversidade de estratégias para o ensino da música. Nesse sentido, temos muito que aprender com os processos informais praticados nos diferentes espaços e contextos da sociedade, não no intuito de transplantá-los para as instituições formais, mas sim com o objetivo de, a partir deles, entender diferentes relações e situações de ensino e aprendizagem da música (QUEIROZ, 2004, p. 102).

Assim como Queiroz (2004; 2005), Penna (2010) defende a valorização da ampliação do universo cultural dos alunos, concebendo o diálogo como um princípio necessário para que isso ocorra e que também trocas de experiências sejam realizadas.

[...] a concepção de música e de arte que embasa a nossa prática pedagógica torna-se suficientemente ampla para abarcar a multiplicidade, indicando o diálogo como prática e princípio para lidar com a diversidade. O diálogo como princípio baseia-se numa concepção dinâmica de cultura, que a entende como 'viva', em constante processo (PENNA, 2010, p. 93).

Conceber o diálogo como princípio também converge com a abordagem de Lemgruber e Oliveira (2011) nos campos da argumentação e da educação. O diálogo é o elemento que propicia a negociação das distâncias entre as diversas culturas que se fazem presentes nas aulas de música.

O diálogo, como estratégia pedagógica que vise a romper com as posturas homogeneizadoras e monoculturais (geralmente valorizadoras de uma cultura eurocêntrica), deve atentar para o fato de que poderá gerar tanto acordos quanto desacordos, pois os alunos, em seu processo formativo, convivem com diferentes educações: a da família, a do grupo religioso, a da comunidade de bairro, etc. Em vista disso, são levados a escolher, a tomarem decisões com relação ao que devem seguir (OLIVEIRA, 2011, p. 93). 
Queiroz (2004, p. 106), que também menciona a importância do diálogo, acrescenta que o mesmo deve ser realizado dentro de um entendimento de que há sentidos e significados diferenciados em relação à música que estão em consonância com cada grupo e/ou contexto cultural:

[...] os diferentes mundos musicais e os distintos processos de transmissão de música em cada sociedade nos fazem perceber que a educação musical está diante de uma pluralidade de contextos, que têm múltiplos universos simbólicos. Dessa maneira, somente criando estratégias plurais e entendendo a música como algo que tem valor em si mesmo, mas que também traz outros sentidos e significados, poderemos pensar num verdadeiro diálogo entre educação musical e cultura. Um diálogo que transpasse o discurso verbal e se insira no discurso musical de cada grupo e/ou contexto social.

O referido autor ainda nos traz algumas contribuições concernentes às possibilidades de contribuição da Educação Musical ao indivíduo, quando consideramos e acolhemos as diferentes culturas e proporcionamos um diálogo entre elas. Tais contribuições em alguma medida, a nosso ver, constituem-se em princípios de trabalho que podem orientar uma prática de Educação Musical em um viés sociocultural.

- experiências educativas que interajam com a realidade de cada cultura; -ensino contextualizado com os diferentes universos musicais da vida cotidiana;

- práticas e vivências musicais que retratem experiências significativas para cada sujeito do processo educativo;

- visão ampla dos valores culturais/musicais da sociedade;

- vivências musicais distintas que permitam ao indivíduo de um determinado contexto conhecer e reconhecer diferentes "sotaques" culturais, inclusive o seu próprio;

- ampliação estética e artístico-musical a partir do conhecimento e da experiência com diferentes aspectos de distintas culturas;

- valorização e aproveitamento do aprendizado musical proporcionado pelos diferentes meios e agentes presentes no processo musical de cada cultura. (QUEIROZ, 2004, p. 105).

Percebemos que as contribuições apresentadas por Queiroz são convergentes com os princípios (diretrizes) propostos por Freire (2011) e ressaltamos que as contribuições apontadas por Queiroz podem se reportar a mais de uma das diretrizes propostas por Freire.

Quando oferecemos "experiências educativas que interajam com a realidade de cada cultura", temos uma relação com o princípio da prática atual, pois este abarca todas as manifestações musicais que se mesclam na contemporaneidade, mas também podemos identificar relação com o princípio de experiência estética e o de construção de conhecimentos.

Oferecer um "ensino contextualizado com os diferentes universos musicais da vida cotidiana" além de se relacionar com o princípio da prática atual remete-nos aos princípios de 
preservação do conhecimento e de historicidade, assim como de experiência estética, que estará presente sempre que a música se fizer "viva". A sociedade possui um acervo musical que é constantemente transformado ao longo da história por meio das reflexões e intervenções realizadas pelo ser humano de acordo com o seu ambiente cultural e, por conseguinte, não existem amarras espaço-temporais para que essa atualização ocorra. Cremos, assim como Freire (2011), que na vida cotidiana existe um presente que abrange resíduos do passado e latências do futuro.

Ao propiciarmos "práticas e vivências musicais que retratem experiências significativas para cada sujeito do processo educativo", podemos reconhecer a presença dos princípios de criação de conhecimento, prática atual, experiência estética e implicação política como ação transformadora. Através das práticas e vivências trazidas ao ambiente educacional, os alunos são capazes de construir conhecimento musical e de refletir sobre esses conteúdos, recriandoos de forma contínua.

Proporcionar uma visão ampla dos valores culturais/musicais da sociedade relacionase, principalmente, aos princípios de preservação do conhecimento e historicidade. Além de os alunos conhecerem distintos acervos culturais presentes na sociedade, eles podem refletir sobre as relações sociais presentes, passadas e também realizar projeções para o futuro, produzindo novos valores.

Quando pensamos em considerar no nosso trabalho pedagógico "as vivências musicais múltiplas que permitam ao indivíduo de um determinado contexto conhecer e reconhecer diferentes 'sotaques' culturais, inclusive o seu próprio" vemos possibilidades de concretizar os princípios de preservação de conhecimento, criação de conhecimento, prática atual, historicidade, reflexão crítica e elaboração teórica.

Podemos também perceber relação com o princípio de preservação de conhecimento, pois entendemos que cada sociedade possui uma bagagem cultural conservada ao longo de sua história que não deve ser considerada como conteúdo fixo, sólido, inflexível, mas passível de uma reflexão crítica e de movimento transformador permanente. $\mathrm{O}$ ato de reconhecer diferentes sotaques nos remete a um acervo cultural que já existe.

Ao promover uma conversa entre os conhecimentos das diferentes bagagens, inclusive com novos saberes, promove-se a oportunidade de construção de conhecimentos, podendo gerar, na prática, uma hibridização entre aspectos do passado e do presente.

A prática atual está assegurada no ato de considerar e acolher, na atualidade, os diferentes sotaques culturais presentes em qualquer época, favorecendo assim, uma prática 
musical multicultural. Isso significa que o indivíduo tem acesso a conhecer novos sotaques, a reconhecer e reelaborar esse conhecimento.

A historicidade está presente como princípio, pois ela busca dar conta das relações socioculturais que permeiam a música para a compreensão do momento histórico vivenciado (seja ele presente, passado ou futuro). Esse princípio também contribui para a conscientização de que cada indivíduo é um agente da história, pois interfere nela permanentemente.

Por fim, constatamos a presença do princípio de reflexão crítica e elaboração teórica, pois falar em sotaques culturais, nos remete, por exemplo, às escolhas e valores envolvidos, o que também envolve limites, convergências e divergências, preconceitos e diferenças em relação às percepções sobre o mundo.

Promover uma "ampliação estética e artístico-musical a partir do conhecimento e da experiência relativa a diferentes aspectos de distintas culturas" tem relação com os princípios de expressão estética, reflexão crítica e elaboração teórica, já que a experiência estética, tal como entendida neste artigo, não deve ser dissociada de uma dimensão reflexiva. Arte gera conhecimento segundo pressuposto assumido neste trabalho. A experiência estética, que realiza a vivência artística, contribui para o pleno desenvolvimento do homem. A experiência estética pressupõe escolhas que envolvem valores em constante interação com a sociedade e suas múltiplas manifestações culturais, devendo ser, na Educação Musical, frequentemente questionados e objeto de reflexão. Os saberes gerados pela arte devem ser elaborados e reelaborados num processo dinâmico e dialógico.

A "valorização e aproveitamento do aprendizado musical proporcionado pelos diferentes meios e agentes presentes no processo musical de cada cultura", a nosso ver, relaciona-se ao princípio de prática atual e à criação de conhecimento. Consideramos a presença do princípio da prática atual quando há receptividade às músicas de diferentes culturas no trabalho pedagógico, não apenas para gerar motivação nos alunos, mas também para que, a partir dela, haja ampliação do conhecimento.

O princípio da criação de conhecimentos também pode ser vislumbrado, pois entendemos que deve haver um diálogo entre o arcabouço de experiências que o aluno já possui, vindo do meio cultural em que o mesmo está inserido, com outros conhecimentos que ele irá construir em sala de aula. Ou seja, o saber é processado dinamicamente, num movimento constante.

As contribuições e princípios trazidos por Queiroz (2004; 2005) e Freire (2011) podem ser analisados pela via do diálogo, ou seja, da argumentação. Sobre a questão do diálogo, Santos et al. (2011, p. 225-226) apontam que nos resta uma opção, 
[...] a de promover o diálogo entre culturas e aproximarmo-nos das músicas de outros grupos culturais como condição para nos voltarmos para a nossa própria prática musical, entendendo-a melhor, mas nunca pelo que lhe parece faltar (SEEGER, 1980; SWANWICK, 2003, p. 36). Esse diálogo possibilita ampliar, expandir a escuta da diversidade cultural presente na própria comunidade onde esse aluno vive ou até mesmo dentro da escola, pois "morar no mesmo bairro ou frequentar a mesma escola não corresponde necessariamente a pertencer à mesma rede de relação social, econômica, simbólica, ideológica" (grifo das autoras).

Consideramos que uma concepção de Educação Musical que valoriza aspectos socioculturais encontra, no diálogo, um caminho fértil para o entendimento de culturas diferenciadas presentes nas aulas de música (FREIRE, 2011; PENNA, 2010; QUEIROZ, 2005; SANTOS et al., 2011) e isso é convergente com a teoria da argumentação aplicada à educação, conforme Lemgruber e Oliveira (2011).

Percebemos que, com base em nossa experiência docente, durante as aulas existe muitas vezes um espaço para o diálogo e questionamento que favorecem a realização de acordos, embora, em certas situações, uma vez firmado um acordo, não exista a possibilidade de se retornar ao questionamento, pois isso significaria permanecer indefinidamente no processo de discussão.

Consideramos que, para contemplar a diversidade das situações pedagógicas, os acordos não devem ser eternos e nem atemporais, todavia é preciso estabelecer limites, já que em qualquer processo argumentativo há também limitações temporais, como frisa Perelman (2004, p. 373):

Ligada a todas as mudanças acarretadas pelo tempo, mudança da pessoa, mudança do contexto argumentativo, a argumentação jamais está definitivamente encerrada; nunca é inútil reforçá-la. Mas, por outro lado, sendo uma ação, a argumentação se situa em limites temporais estritos. A duração de um discurso é em geral minuciosamente controlada, a atenção do ouvinte não pode prolongar-se indefinidamente; a urgência da decisão impede que se prossigam os debates, mesmo que as incertezas não tenham sido dominadas, mesmo que todos os ângulos do problema não possam ter sido examinados de modo exaustivo.

A todo o momento, neste trabalho, estamos argumentando em prol de aulas de música que considerem os fatores socioculturais, considerando que eles condicionam os diferentes auditórios e também são condicionados por eles. Todavia, temos que nos preocupar em não valorizar um grupo cultural específico, podendo gerar uma "guetização" (PENNA, 2010) ou uma situação de privilégio monocultural. Inclusive, podemos dizer que a guetização é uma das críticas direcionadas ao multiculturalismo, pois podemos privilegiar um grupo em detrimento 
do outro, incentivando, mesmo sem tal intenção, que grupos culturais específicos só dialoguem entre sim, que vivam somente no seu "mundo".

O que defendemos aqui é que esses diferentes grupos convivam e se relacionem na sociedade e, consequentemente, no espaço escolar, possibilitando debates e reflexões constantes a respeito dessas diferenças. Sabemos que isso não é uma tarefa fácil, mas constitui um desafio permanente.

Defendemos que o "lugar" da diversidade não é o da aceitação e o da tolerância, muito menos o da concordância, mas sim o do respeito. Se dizemos que aceitamos ou toleramos alguém ou alguma situação, em alguma medida já criamos um distanciamento e uma hierarquia entre nós e o outro. Para estabelecermos um acordo, que é diferente de concordância, temos que procurar minimizar as distâncias que nos separam do outro e para isso precisamos ceder, não de modo acrítico, mas reflexivo! (OLIVEIRA; OLIVEIRA, 2018, p. 207-208).

Sekeff (2007) também considera a música como saber cultural relacionada a uma comunidade específica que favorece a integração e criação de identidade no sistema social do qual o indivíduo faz parte, identidade essa que se perpetua e que se autorreorganiza constantemente.

Variar o trabalho pedagógico dando espaço para a contribuição de diferentes culturas, valorizando diversos códigos musicais e também promovendo a integração entre as mesmas são formas de afastar uma perspectiva monocultural nas aulas de música.

No campo da educação, a guetização levaria a propostas curriculares que se voltam exclusivamente ao estudo dos padrões culturais específicos do grupo. Essa postura é bastante reducionista, se pensarmos no amplo e diversificado patrimônio artístico e cultural da humanidade, se considerarmos a multiplicidade quase infinita de manifestações musicais, expressando poéticas diferenciadas. [...] Muitas vezes a guetização está ligada a uma idealização das raízes culturais, levando ao "congelamento" ou "fixação" de práticas culturais, o que nega o caráter vivo e dinâmico da cultura e da sociedade (PENNA, 2010, p. 96).

A respeito desse assunto, Santos et al. nos trazem a seguinte contribuição:

Na situação escolar, as músicas vêm carregadas de significados e enredadas pelo contexto-social aos quais os sujeitos-alunos as remetem. Mas a escola acaba "museificando" o fato cultural em nome de uma suposta pureza; ou celebrando identidades fixadas em bens culturais representativos de uma comunidade étnica, nacional ou regional e até constituindo guetos musicais [...] (2011, p. 225).

Penna (2010) e Santos et al. (2011) levantam uma questão para a qual devemos estar atentos: a solidificação de práticas culturais, risco que corremos, muitas vezes, ao contemplar 
um grupo em detrimento do outro. Reiteramos nossa compreensão de que, em se tratando de auditórios heterogêneos, não cabe considerar pureza cultural, nem fixar padrões culturais ideais, pois o processo sociocultural, além de diversificado, está em constante movimento, ou seja, é dinâmico.

Lidar com oradores/auditórios que possuem demandas musicais desiguais é algo a ser discutido e refletido constantemente pelos docentes atuantes e também por aqueles que estão em processo de formação. O diálogo entre culturas deve ser fomentado, assim como o diálogo entre o educador e as possibilidades musicais existentes.

Ambientes musicais variados propiciam que o professor de música amplie a sua ação pedagógica. O reconhecimento dessa diversidade tem afetado a formação docente quanto às competências (pessoais e didático-metodológicas) que são necessárias para atuar em diferentes locais. Para trabalhar com uma visão cultural aberta em relação ao ensino da música, cremos que deva haver uma ressignificação de valores musicais por parte dos docentes, alunos e instituições de ensino de forma geral. Ou seja, não devemos eleger os valores musicais de uma única cultura como superiores em detrimento de valores de outras culturas. Todas as culturas têm algo a oferecer para a construção de conhecimento musical. Além disso,

[...] os múltiplos contextos musicais exigem do educador abordagens múltiplas nas suas formas de ouvir, fazer, ensinar, aprender e dialogar com a música. Essa perspectiva de educação musical, que tem afetado diretamente os processos educativos e as competências necessárias para a formação do professor de música, tem possibilitado também uma ressignificação dos valores musicais do ensino formal. Já se comprovou que qualquer processo que enfoque uma única visão cultural acaba acarretando uma dominação inapropriada, dominação que tende a favorecer uma prática educacional unilateral, que privilegia um sistema cultural em detrimento de outros (QUEIROZ, 2004, p. 105).

Outro aspecto a destacar é que há limites no trabalho de Educação Musical em relação à possibilidade de abranger as diferentes manifestações e perspectivas musicais que cada cultura apresenta. Sobre isso, Queiroz (2004, p. 103) observa que

É evidente que nenhuma proposta de educação musical vai contemplar todos os universos musicais existentes em uma cultura. No entanto, entender processos de transmissão de música em diferentes situações, espaços e contextos culturais permite a realização de propostas coerentes para o ensino musical. Assim, acreditamos que a partir do conhecimento de distintas perspectivas do ensino e aprendizagem da música, o educador estará mais apto para a (re) apropriação e/ou a criação de estratégias metodológicas capazes de abarcar diferentes dimensões da educação musical.

Na medida em que estamos imersos num mundo plural em que as subjetividades estão em constante definição e redefinição, entendemos que as respostas “certas”, cristalizadas e fixas 
no trabalho pedagógico não existem. O que existe são acordos plausíveis, verossímeis e provisórios que podem ser estabelecidos, em consonância com as diferentes culturas presentes no âmbito educativo.

Nossos alunos são sujeitos de um mundo plural, onde as noções de tempo, espaço, limite e fronteiras já não cabem mais no modelo cartesiano, e onde valores culturais perdem a rota das tradições e se definem nas escolhas e usos de bens de consumo descartáveis materiais, sociais e intelectuais. Hoje somos atravessados por uma rede de subjetividades resultantes de muitos mundos, colocando-nos ante o contraditório, o bizarro, o inesperado e impondo questões para as quais já não existem "respostas certas" (SANTOS et al., 2011, p. 222).

Por fim, consideramos que a citação de Queiroz, a seguir, assemelha-se à intenção deste capítulo, pois nos propomos a refletir e a defender uma Educação Musical que tenha um olhar sociocultural abrangente:

[...] a relação entre educação musical e cultura é estabelecida pelas próprias relações do homem com a música. Assim, não se pode pensar em um processo educacional desvinculado dos demais aspectos da cultura particular de cada grupo social. Da mesma forma, espera-se da educação musical não somente uma conformidade com o sistema cultural de uma sociedade, mas sim uma interferência neste, possibilitando a autonomia dos seus sujeitos para configurar novas concepções de música e suas relações (QUEIROZ, 2004, p. 105).

\section{Considerações finais}

Muitas foram as motivações para realizar esse recorte de nossa tese. Uma delas é que encontramos inúmeras produções que defendem que valorizemos a realidade do discente e seus aspectos socioculturais em termos teóricos e uma quantidade menor que focaliza como podemos realizá-la com sugestões e princípios aliados à prática. Acreditamos que conseguimos relacionar teoria e prática ao abordar concepções de Educação Musical de cunho sociocultural.

Com base nos autores e discussões realizadas, consideramos que a atuação de educadores e estudantes está permeada de elementos oriundos de seu universo sociocultural, que, a nosso ver, não determinam, mas condicionam, influenciam e regulam nosso agir. A manifestação dessas culturas e seu(s) encontro(s) não ocorrem de modo neutro e ingênuo, muito pelo contrário, eles se mostram, na maioria das situações, de maneira conflituosa, contraditória e desafiadora, até porque como foi apontado no texto, as diferentes culturas podem confluir, distanciar-se e até mesmo amalgamar-se.

Nesse contexto, a Educação Musical sob a perspectiva sociocultural aponta alguns caminhos de reflexão e de ação para que esse processo ocorra de modo satisfatório sem 
neutralizar as diferenças ali representadas por diferentes oradores e auditórios, mas procurando colocá-las em diálogo, em uma dinâmica constante de negociação de distâncias, a fim de que os diversos mundos e idiomas musicais possam ter um espaço nas aulas de músicas cujos objetivos são, entre outros, a formação musical ampla e consistente, o desenvolvimento do pensamento crítico, a transformação social e o aprimoramento estético.

Observamos que as reflexões que foram dirigidas à área da Educação Musical também podem servir às demais áreas de ensino, apesar de a presente não ter sido realizada com objetivos de generalização. Mesmo reconhecendo as peculiaridades de cada área de conhecimento, consideramos que as discussões aqui travadas podem ser relativamente aplicáveis a elas.

\section{REFERÊNCIAS}

ÁLVARES, Thelma Sydenstricker; AMARANTE, Paulo (Orgs.). Educação musical na diversidade: construindo um olhar de reconhecimento humano e equidade social em Educação. Curitiba: CRV, 2016.

BLACKING, John. How musical is man? 5. ed. London: Universit of Washington Press, 1995.

BLACKING, John. Música, cultura e experiência. Tradução de André-Kees de Moraes Schouten. São Paulo: Departamento de Antropologia/FFLCH/USP, 2007, p. 201-218.

CANEN, Ana. O Multiculturalismo e seus dilemas: implicações na educação. Comunicação \& Política, Rio de Janeiro, v. 25, n. 2, p. 91-107, 2007.

CANEN, Ana; ARBACHE, Ana Paula; FRANCO, Monique. Pesquisando multiculturalismo e educação: o que dizem as dissertações e teses. Educação \& Realidade, Porto Alegre, v. 26, n. 1, p. 161-181, jun./jul. 2001.

CANEN, Ana; OLIVEIRA, Ângela M. A. de. Multiculturalismo e currículo em ação: um estudo de caso. Revista Brasileira de Educação, Rio de Janeiro, n. 21, p. 61-74, set./dez. 2002.

CASSIRER, Ernst. Antropologia filosófica. São Paulo: Mestre Jou, 1977.

FISCHER, Ernst. A necessidade da arte. São Paulo: Círculo do Livro, [s.d.].

FREIRE, Vanda Bellard. Currículos, apreciação musical e culturas brasileiras. Revista da ABEM, Porto Alegre, V. 6, p. 69-72, set. 2001.

FREIRE, Vanda Bellard. Música e Sociedade: uma perspectiva histórica e uma reflexão aplicada ao Ensino Superior de Música. 2. ed. Florianópolis: Associação Brasileira de Educação Musical, 2011.

GEERTZ, Clifford. The interpretation of cultures. London: Hutchinson, 1975. 
GIROUX, Henry; SIMON, Roger. Cultura Popular e Pedagogia Crítica: a vida cotidiana como base para o conhecimento curricular. In: MOREIRA, Antônio Flávio; SILVA, Tomaz Tadeu da (Org.). Currículo, cultura e sociedade. 2. ed. São Paulo: Cortez, 1995. p. 93-124.

GONÇALVES, Luiz Alberto Oliveira; SILVA, Petronilha Beatriz Gonçalves e. O jogo das diferenças: o multiculturalismo e seus contextos. 3. ed. Belo Horizonte: Autêntica, 2002.

HERNDON, Marcia; MCLEOD, N. Music as culture. Norwood: Norwood Editions, 1980.

LEMGRUBER, Márcio Silveira; OLIVEIRA, Renato José de. Argumentação e Educação: da ágora às nuvens. In: LEMGRUBER, Márcio Silveira; OLIVEIRA, Renato José de (Org.). Teoria da argumentação e educação. Juiz de Fora: Editora UFJF, 2011.

MEYER, Michel. A problematologia como chave para a unidade da retórica. In: MEYER, Michel; CARRILHO, Manuel Maria; TIMMERMANS, Benoit. História da Retórica. Lisboa: Temas e Debates, 2002. p. 265-298.

MOLINO, Jean. Facto Musical e Semiologia da Música. In: NATTIEZ, J-J et al. Semiologia da Música. Lisboa: Veja, s/d, p. 17-40.

MOREIRA, Herivelto; CALEFFE, Luiz Gonzaga. Metodologia da pesquisa para o professor pesquisador. 2. ed. Rio de Janeiro: Lamparina, 2008.

NETTL, Bruno. The Study of ethnomusicology: twenty-nine issues and concepts. Urbana, Illinois: University of Illinois Press, 1983.

OLIVEIRA, Renato José de (Org.). A Nova Retórica, a problematologia e a educação. In: LEMBRUGER, Márcio Silveira; OLIVEIRA, Renato José de (Org.). Teoria da Argumentação e educação. Juiz de Fora: UFJF, 2011. p. 91-106.

OLIVEIRA, Renato José de; CANEN, Ana; FRANCO, Monique. Ética, multiculturalismo e educação. Revista Brasileira de Educação, n. 13, p. 113-126, jan./abr., 2000.

OLIVEIRA, Renato José de; OLIVEIRA, Helen Silveira Jardim de. Retórica e argumentação: contribuições para a educação escolar. Educar em Revista, Curitiba, v. 34, n. 70, p. 197-212, jul./ago. 2018.

PENNA, Maura. Música(s) e seu ensino. 2. Ed. Porto Alegre: Sulina, 2010.

PERELMAN, Chaïm. Retóricas. 2. ed. São Paulo: Martins Fontes, 2004.

PERELMAN, Chaïm; OLBRECHTS-TYTECA, Lucie. Tratado da argumentação: a nova retórica. 6. ed. São Paulo: Martins Fontes, 2005.

QUEIROZ, Luis Ricardo Silva. Educação musical e etnomusicologia: uma reflexão sobre as contribuições do estudo etnomusicológico para a área de educação musical. In: Congresso da Associação Nacional de Pesquisa e Pós-Graduação em Música, 14., 2003, Porto Alegre. Anais [...] Porto Alegre: ANPPOM, p. 772-779, 2003. [1 CD-ROM]. 
QUEIROZ, Luis Ricardo Silva. Educação musical e cultura: singularidade e pluralidade cultural no ensino e aprendizagem da música. Revista da ABEM, Porto Alegre, V. 10, p. 99107, mar. 2004.

QUEIROZ, Luis Ricardo Silva. A música como fenômeno sociocultural. In: MARINHO, Vanildo Mousinho; QUEIROZ, Luis Ricardo Silva (Org.). Contexturas: o ensino das artes em diferentes espaços. João Pessoa: Editora Universitária/UFPB, 2005.

READ, Herbert. As origens da forma na arte. Rio de Janeiro: Zahar, 1981.

READ, Herbert. A educação pela arte. São Paulo: Martins Fontes, 1982.

SANTOS, Regina Marcia Simão (Org.); DIDIER, Adriana Rodrigues; VIEIRA, Eliane Maria; ALFONZO, Neila Ruiz. Música, cultura e educação: os múltiplos espaços de educação musical. Porto Alegre: Sulina, 2011.

SEEGER, Anthony. Os índios e nós: estudos sobre sociedades tribais brasileiras. Rio de Janeiro: Campus, 1980.

SEKEFF, Maria de Lourdes. Da música: seus usos e recursos. 2.ed. São Paulo: UNESP, 2007.

SOUZA SANTOS, Boaventura de. Dilemas do nosso tempo: globalização, multiculturalismo e conhecimento. Educação e Realidade, Porto Alegre: Universidade Federal do Rio Grande do Sul, V. 26, n. 1, p. 13-32, 2001.

SWANWICK, Keith. Ensinando música musicalmente. Tradução Alda Oliveira e Cristina Tourinho. São Paulo: Moderna, 2003.

VEIGA-NETO, Alfredo. De geometrias, currículo e diferenças. Educação e sociedade, Campinas, v. 23 n. 79, p. 163-186, ago. 2002.

YIN, Robert K. Estudo de caso: planejamento e métodos. Tradução de Ana Thorell. 4. ed. Porto Alegre: Bookman, 2010.

\section{Como citar este artigo}

OLIVEIRA, Helen Silveira Jardim de. Educação musical segundo uma perspectiva sociocultural: reflexões teóricas e práticas. Revista on line de Política e Gestão Educacional, Araraquara, v. 23, n. 3, p. 592-622, set./dez., 2019. E-ISSN:1519-9029. DOI: 10.22633/rpge.v23i3.12779

Data de Submissão: 06/04/2019

Revisões Requeridas: 08/06/2019

Aceite em: 15/07/2019

Publicado em: 15/08/2019 